[Letter]

\title{
Initiation of Oxidative Reforming of Butane over Praseodymium Oxide Supported Ni Catalysts at Ambient Temperature
}

\author{
Katsutoshi Sato ${ }^{1,2)}$, Katsutoshi Nagaoka ${ }^{1) *}$, Hiroyasu Nishiguchi ${ }^{\text {() }}$, and Yusaku Takita ${ }^{1)}$ \\ 1) Dept. of Applied Chemistry, Faculty of Engineering, Oita University, Dannoharu 700, Oita 870-1192, JAPAN
}

2) Research Fellow of the Japan Society for the Promotion of Science (DC)

(Received May 7, 2009)

The catalytic characteristics of various rare-earth oxide supports for Ni catalysts were investigated for the initiation of the oxidative reforming (OR) of $\mathrm{C}_{4} \mathrm{H}_{10}$ at ambient temperature. $\mathrm{Ni} / \mathrm{PrO}_{1.83}$, reduced at $873 \mathrm{~K}$, successfully initiated the OR of $\mathrm{C}_{4} \mathrm{H}_{10}$ as previously reported for $\mathrm{Ni} / \mathrm{CeO}_{2}$. $\mathrm{PrO}_{1.83}$ undergoes reduction by $\mathrm{H}_{2}$ at $873 \mathrm{~K}$ and subsequent oxidation at ambient temperature, so the catalyst is heated to initiate the auto-ignition temperature $(633 \mathrm{~K})$ of $\mathrm{C}_{4} \mathrm{H}_{10}$ OR over the catalyst.

Keywords: Oxidative reforming, Ambient temperature triggering, Rare-earth oxide, Praseodymium oxide, Nickel catalyst

Fuel cells (FC), which require hydrogen fuel, are expected to become an important type of next-generation power generators because of their high energy efficiency and low emissions of harmful effluent gases ${ }^{1)}$. In recent years, the use of FC systems for domestic purposes has attracted considerable attention, but such an application would require repeated start-ups and shut-downs of the system. Therefore, an effective yet simple and rapid start-up process for the on-site reformer incorporated in FC systems is highly desirable. To develop such a system for FC systems, we have developed a new catalytic reforming process, which involves the initiation of oxidative reforming (OR) of $\mathrm{C}_{4} \mathrm{H}_{10}$ over partially reduced $\mathrm{Rh} / \mathrm{CeO}_{2}$ or $\mathrm{Ni} / \mathrm{CeO}_{2}$ catalyst at ambient temperature ${ }^{2,3)}$. The reduced catalyst support, $\mathrm{CeO}_{2-\mathrm{x}}$, is oxidized spontaneously by $\mathrm{O}_{2}$ present in the reaction mixture, resulting in the generation of heat $^{4)}$, so that the temperature of the catalyst bed rapidly increases above $523 \mathrm{~K}$ (this temperature is referred to as the catalytic autoignition temperature over $\mathrm{Rh} / \mathrm{CeO}_{2}$ ) and the $\mathrm{OR}$ is initiated. This process allows a novel step-up approach, by which heat is generated intemally, without requiring an external source of energy or a special start-up procedure.

The present study investigated new catalyst supports suitable for use in the OR of $\mathrm{C}_{4} \mathrm{H}_{10}$ at ambient temperatures using $\mathrm{Ni}$ catalyst supported on different types of rare-earth oxides such as $\mathrm{CeO}_{2}$. In addition, desirable properties of the catalytic support required to trigger the $\mathrm{OR}$ at room temperature were investigated.

The supported $\mathrm{Ni}$ catalysts were prepared by the wet impregnation method with various rare-earth oxides and an aqueous solution of $\mathrm{Ni}\left(\mathrm{NO}_{3}\right)_{2} \cdot 6 \mathrm{H}_{2} \mathrm{O}$ (Wako Pure Chemicals Industries, Ltd., Japan). The loading of the catalyst metal was fixed at $20 \mathrm{wt} \%$. The catalysts were calcined at $923 \mathrm{~K}$ for $5 \mathrm{~h}$ under an air stream. Activity tests on the catalysts were performed under nonadiabatic conditions. $100 \mathrm{mg}$ of the catalyst

“酸化ア゚ラセオジム担持 Ni触媒を用いたブタンの酸化的改質反応の常温駆動”

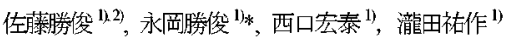

1) 大分大学工学部応用化学科, 870-1192 大分市旦野原 700

2) 日本学術振興会 特別研究員 (DC)

*Corresponding author, E-mail: nagaoka(axc. oita-u.ac.jp was loaded in a tubular quartz reactor. A K-type thermocouple was inserted in the catalyst bed to measure the catalyst bed temperature. The catalysts were reduced in pure $\mathrm{H}_{2}$ at $873 \mathrm{~K}$ for $1 \mathrm{~h}$, purged with pure $\mathrm{Ar}$, and then cooled to ambient temperature. The furnace heater was then kept switched off throughout the test. A gas mixture of $\mathrm{C}_{4} \mathrm{H}_{10} / \mathrm{O}_{2} / \mathrm{Ar}=1 / 2 / 12$ (SV $=333 \mathrm{~L} /(\mathrm{h} \cdot \mathrm{g})$ ) was used as the feed and passed over each catalyst at ambient temperature. After allowing the reaction to take place for $30 \mathrm{~min}$, the products obtained were analyzed using a GC-TCD. The reaction was terminated after $35 \mathrm{~min}$ by substituting the feed gas mixture with Ar. Details of the calculation (conversions and yields) and characterization methods were described previously ${ }^{2,3)}$.

The conversion, yields of products, and the $\mathrm{H}_{2}$ formation rate are summarized in Table 1 . The $\mathrm{Ni} / \mathrm{PrO}_{1.83}$ catalyst bed temperatures increased spontaneously above $873 \mathrm{~K}$ within $12 \mathrm{~s}$ after flow of the gas mixture was started following reduction. The $\mathrm{Ni} / \mathrm{PrO} \mathrm{O}_{1.83}$ catalyst provided complete $\mathrm{O}_{2}$ consumption and $86 \% \mathrm{C}_{4} \mathrm{H}_{10}$ conversion after $30 \mathrm{~min}$. The reaction products obtained were $\mathrm{H}_{2}, \mathrm{CO}_{2}, \mathrm{CO}, \mathrm{H}_{2} \mathrm{O}$, and $\mathrm{CH}_{4} . \mathrm{H}_{2}$ and $\mathrm{CO}$ were the major products with yields of over $60 \%$. In addition, the $\mathrm{H}_{2}$ formation rate was above $70 \mathrm{~L} /(\mathrm{h} \cdot \mathrm{g})$. In contrast, the catalyst bed temperature of all other Ni catalysts did not increase even after flow of the reaction mixture was started. Additionally, the levels of the products from these catalysts after $30 \mathrm{~min}$ were below the detection limit of the thermal conductivity detector (TCD). Therefore, only $\mathrm{Ni} / \mathrm{PrO}_{1.83}$ successfully catalyzed the $\mathrm{OR}$ of

Table 1 Catalytic Behavior of Ni Catalysts Supported on Rare-earth Oxides Reduced at $873 \mathrm{~K}$

\begin{tabular}{|c|c|c|c|c|c|c|c|}
\hline \multirow[t]{2}{*}{ Catalyst } & \multicolumn{2}{|c|}{$\begin{array}{c}\text { Conversion } \\
{[\%]}\end{array}$} & \multicolumn{4}{|c|}{$\begin{array}{c}\text { Yield }^{a)} \\
{[\%]}\end{array}$} & \multirow[t]{2}{*}{$\begin{array}{c}\mathrm{H}_{2} \text { formation rate } \\
{[\mathrm{L} /(\mathbf{h} \cdot \mathbf{g})]}\end{array}$} \\
\hline & $\mathrm{C}_{4} \mathrm{H}_{10}$ & $\mathrm{O}_{2}$ & $\mathrm{H}_{2}$ & $\mathrm{CO}_{2}$ & $\mathrm{CO}$ & $\mathrm{CH}_{4}$ & \\
\hline $\mathrm{Ni} / \mathrm{PrO}_{1.83}$ & 86.0 & 100 & 65.8 & 12.3 & 64.0 & 4.4 & 73.0 \\
\hline $\mathrm{Ni} / \mathrm{TbO}_{1.75}$ & 0 & 0 & - & - & - & - & 0 \\
\hline $\mathrm{Ni} / \mathrm{YbO}_{1.5}$ & 0 & 0 & - & - & - & - & 0 \\
\hline $\mathrm{Ni} / \mathrm{HoO}_{1.5}$ & 0 & 0 & - & - & - & - & 0 \\
\hline $\mathrm{Ni} / \mathrm{GdO}_{1.5}$ & 0 & 0 & - & - & - & - & 0 \\
\hline $\mathrm{Ni} / \mathrm{SmO}_{1.5}$ & 0 & 0 & - & - & - & - & 0 \\
\hline
\end{tabular}

a) measured after feeding reaction mixture for $30 \mathrm{~min}$. 

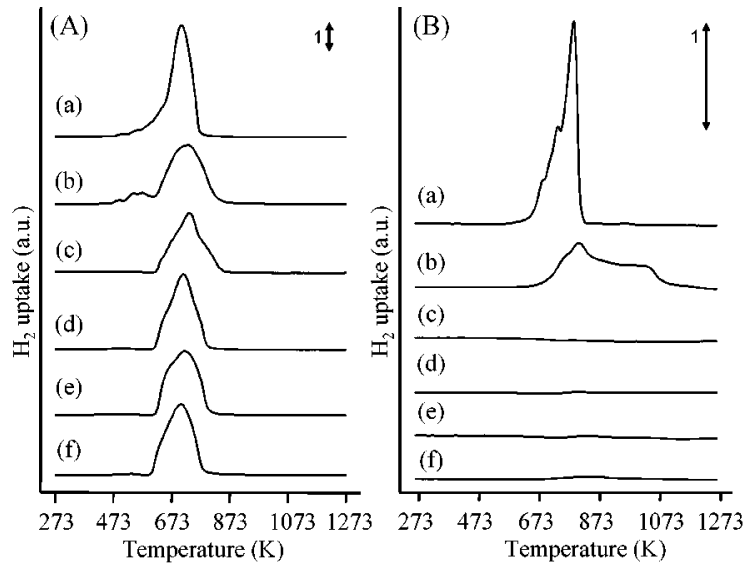

Fig. 1. TPR Profiles of Supported Ni Catalysts (A) and Rare-earth Oxides without $\mathrm{Ni}$ (B); (a): $\mathrm{PrO}_{1.83}$, (b): $\mathrm{TbO}_{1,75}$, (c): $\mathrm{YbO}_{1.5}$, (d): $\mathrm{HoO}_{1.5},(\mathrm{e}): \mathrm{GdO}_{1.5},(\mathrm{f}): \mathrm{SmO}_{1.5}$

\section{$\mathrm{C}_{4} \mathrm{H}_{10}$ at temperature.}

To investigate why only $\mathrm{Ni} / \mathrm{PrO}_{1.83}$ successfully catalyzed the $\mathrm{OR}$ of $\mathrm{C}_{4} \mathrm{H}_{10}$ at ambient temperature, we further examined the character of the catalysts. As already mentioned, spontaneous oxidation by $\mathrm{O}_{2}$ of the partially reduced catalyst support is the key step in triggering the OR of $\mathrm{C}_{4} \mathrm{H}_{10}{ }^{2}$. To compare the reduction process of the catalysts, the temperature programmed reduction (TPR) profiles of all the catalysts were measured. Figure 1(A) shows the TPR profiles of the supported $\mathrm{Ni}$ catalyst. $\mathrm{H}_{2}$ consumption was observed at approximately $500-800 \mathrm{~K}$ in the profiles of all catalysts. In the cases of $\mathrm{Ni} / \mathrm{YbO}_{1.5}, \mathrm{Ni} / \mathrm{HoO}_{1.5}, \mathrm{Ni} / \mathrm{GdO}_{1.5}$, and $\mathrm{Ni} / \mathrm{SmO}_{1.5}$, the amount of $\mathrm{H}_{2}$ consumed coincided with the amount of $\mathrm{H}_{2}$ required to completely reduce the supported $\mathrm{NiO}$ to $\mathrm{Ni}^{0}$. In contrast, in the cases of $\mathrm{Ni} / \mathrm{PrO}_{1.83}$ and $\mathrm{Ni} / \mathrm{TbO}_{1.75}$, the amount of $\mathrm{H}_{2}$ consumed was higher than that required for the complete reduction of NiO. These findings imply that the rare-earth oxides of the supports of $\mathrm{Ni} / \mathrm{PrO}_{1.83}$ and $\mathrm{Ni} / \mathrm{TbO}_{1.75}$ were reduced in addition to $\mathrm{NiO}$. Assuming that complete reduction to $\mathrm{Ni}^{0}$ occurred, the stoichiometries of the supports were determined to be $\mathrm{PrO}_{1.54}$ and $\mathrm{TbO}_{1.58}$ after TPR measurements. Figure 1(B) shows the TPR profiles for the bare rare-earth oxides. The TPR profiles of $\mathrm{PrO}_{1.83}$ and $\mathrm{TbO}_{175}$ showed some peaks, whereas the profiles of other rare-earth oxides showed no such peaks. These results support the finding that only $\mathrm{PrO}_{1.83}$, and $\mathrm{TbO}_{1.75}$ were reduced by $\mathrm{H}_{2}$ among the oxides studied. To evaluate the generation of heat by the oxidation of the reduced catalysts, an $\mathrm{O}_{2}$-Ar mixture was passed over $\mathrm{Ni} / \mathrm{PrO}_{183}$, which was reduced at $873 \mathrm{~K}$. The catalyst bed temperatures increased to above $753 \mathrm{~K}$ in contact with this gas mixture at ambient temperature, which higher than the autoigniton temperature of $\mathrm{Ni} / \mathrm{PrO}_{1.83}(633 \mathrm{~K})$. This result indicates that catalyst bed was heated internally and initiates the oxidation of $\mathrm{C}_{4} \mathrm{H}_{10}$ and subsequent reforming. However, no increase in the catalyst bed temperature was observed, even if $\mathrm{O}_{2}$-Ar mixture was passed over $\mathrm{Ni} / \mathrm{TbO}_{1.75}$ reduced at $873 \mathrm{~K}$.

$\mathrm{X}$-ray diffraction was used to compare the structures of $\mathrm{Ni} / \mathrm{PrO}_{1.83}$ and $\mathrm{Ni} / \mathrm{TbO}_{1.75}$ before and after reduction followed by exposure to an $\mathrm{O}_{2}$-Ar mixture (Fig. 2). The XRD spectra
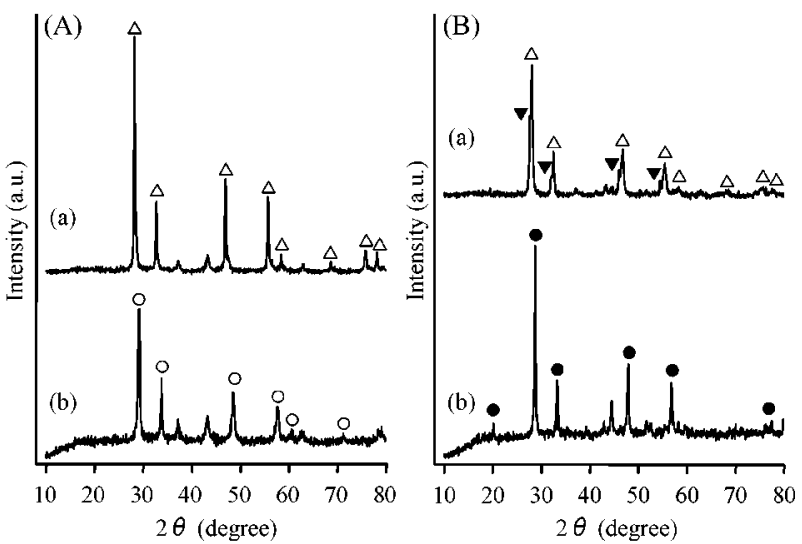

Fig. 2. XRD Patterns of Supported Ni Catalysts after Calcination (A) and after Reduction (B); (a): $\mathrm{Ni} / \mathrm{PrO}_{1.83}$, (b): $\mathrm{Ni} / \mathrm{TbO}_{1.75}$ ( $\triangle$ ): $\mathrm{PrO}_{1.83},(\boldsymbol{\nabla}): \mathrm{PrO}_{1.5},(\mathrm{O}): \mathrm{TbO}_{1.75},(\mathrm{O}): \mathrm{TbO}_{1.5}$

indicated fluorite-type structures for both $\mathrm{PrO}_{1.83}$ and $\mathrm{TbO}_{1.75}$, which mainly contain $\operatorname{Pr}^{4+}$ and $\mathrm{Tb}^{4+}$, before reduction. The XRD spectra of $\mathrm{Ni} / \mathrm{PrO}_{1.83}$ showed both the fluorite-type structure for $\mathrm{PrO}_{1.83}$ as well as the sesqui-oxide type structure for $\mathrm{PrO}_{1.5}$ containing $\operatorname{Pr}^{3+}$ after reduction followed by passing the $\mathrm{O}_{2}-\mathrm{Ar}$ mixture. Therefore, the support of $\mathrm{Ni} / \mathrm{PrO}_{1.83}$ was reduced to $\mathrm{PrO}_{1,54}$ by $\mathrm{H}_{2}$ reduction, suggesting that about $90 \%$ of $\mathrm{Pr}^{4+}$ was reduced. Subsequently, the reduced praseodymium oxide $\left(\mathrm{PrO}_{1.54}\right)$ was more or less oxidized to $\mathrm{PrO}_{1.83}$ by exposure to $\mathrm{O}_{2}$ and the catalyst bed was heated to $753 \mathrm{~K}$, as observed for supported $\mathrm{CeO}_{2}$ catalysts ${ }^{2)}$. On the other hand, the XRD spectrum of $\mathrm{Ni} / \mathrm{TbO}_{175}$ after reduction followed by passing an $\mathrm{O}_{2}$ mixture only showed peaks assignable to $\mathrm{TbO}_{1.5}$ containing only $\mathrm{Tb}^{3+}$, which is approximately in accordance with TPR results. These results suggest that $\mathrm{TbO}_{1.5}$ was not oxidized to $\mathrm{TbO}_{1.75}$ by $\mathrm{O}_{2}$ at ambient temperature. Therefore, $\mathrm{TbO}_{1.5}$ was stable at ambient temperature and was not oxidized, so that the catalyst bed temperature did not increase to the autoignition temperature.

The present study found that the new catalyst, $\mathrm{Ni} / \mathrm{PrO}_{183}$, initiates the $\mathrm{OR}$ of $\mathrm{C}_{4} \mathrm{H}_{10}$ at ambient temperature, because of the intrinsic characteristics of reduction by $\mathrm{H}_{2}$ at $873 \mathrm{~K}$ and easy oxidation at ambient temperature. These reduction and oxidation properties of the material are important for initiating the OR at ambient temperature.

\section{References}

1) Cheekatamarla, K. P., Finnertya C. M., J. Power Sources, 160, 490 (2006).

2) Nagaoka, K., Sato, K., Fukuda, S., N akashiki, S., Nishiguchi, H., Lercher, A. J., Takita, Y., Chem. Mater, 20, 4176 (2008).

3) Sato, K., Adachi K., Nagaoka, K., Nishiguchi, H., Takita, Y., Catal. Commm, 10, 1478 (2009).

4) Ruckenstein, E., Wang, Y. H., J. Catal, 187, 151 (1999).

5) Sata, T., Yoshimura, M., J. Ceramic Assoc. Japam, 76, 116 (1968).

Acknowledgments: This study was partly supported by a Grant for Research from The Japan Petroleum Institute, Grant in Aid for JSPS Fellows, the Nippon Sheet Glass Foundation for Materials Science and Engineering and Linking mechanism of research results to practical application from Japan Science and Technology Agency. 